\title{
The Facilitating State and Economic Development: The Role of the State in New Structural Economics ${ }^{1}$
}

\begin{abstract}
This paper explores the ideas of development and the role of the state in economic development and institutional change from the New Structural Economics perspective. We argue that economic structures - including the structure of technology and industry, and hard and soft infrastructure - are endogenous to the endowment structure, which is given at any specific time and changeable over time. We advocate a state to facilitate structural change by using industrial policy to overcome market failures in order to help industries with latent comparative advantages to become competitive in the market and the state should pragmatically prioritize the use of its limited resources and implementation capability to create enclaves with favourable infrastructure and institution to jump start a dynamic growth in a country beset with poor infrastructure and institution.
\end{abstract}

Keywords: Role of the State; Economic Development; New Structural Economics.

\section{Introduction}

After the World War II, many countries gained political independence and started their drive to modernization. In response to the need for nation building in developing countries, a new sub-discipline in modern economics emerged: development economics. It was hoped that development economics would guide developing countries through the process of industrialization and help them achieve prosperity.

However, the results are disappointing. Among nearly 200 developing economies only South Korea and Taiwan, China have moved from low-income to high-income status (Lin and Rosenblatt 2014); ${ }^{2}$ and among the 110 middle-income economies in the 1960 , only 13 moved from middle-income

Published on Man and the Economy, vol. 4(2), December, 2017, pages 1-19.

2 It is likely that mainland China will become the third economy that transformed from low income to high income in around 2025. 
to high-income (Agenor et al 2012). Of those 13 economies, eight were either countries surrounding Western Europe, whose gaps with developed countries were small to begin with, or oil-producing countries. The other five were Japan, Korea, Taiwan, Hong Kong, and Singapore.

The seminal Solow growth model predicts convergence in income as poor countries should grow faster than rich countries due to diminishing returns to capital (Solow 1956). However, despite both the efforts made by developing countries and the assistance of many multilateral development agencies, most developing economies failed to catch up with the high-income economies. This phenomenon is puzzling.

Mankiw et al (1992) argues that an augmented Solow model that includes accumulation of human as well as physical capital provides an excellent description of the cross-country data. Following a similar principle to that applied to physical capital, lower levels of human capital should mean a higher rate of return. However, poor countries are unable to accumulate enough human capital due to lack of investment in high quality education and also because there were significant brain-drain problems. This is similar problem to that of the capital flight from poor countries to rich counties (Lucas 1990). Thus lower physical capital and human capital are the results of something more fundamental that is at the root of the growth failures.

The nature of modern income growth is, as Kuznets (1966) argues, a process of continuous structural transformation with continuous technological innovation in existing industrial and emergence of new higher value-added industries, which raise labor productivity, and improvement in hard (tangible) infrastructure and soft (intangible) infrastructure (institution), which reduce transaction costs in the economy. As developing countries are relatively backward in terms of technology and industries they should have the potential to grow faster than developed countries and achieve convergence as result of the ease of improving their technology and upgrading their industries (Gerschenkron 1962). However, most developing countries have not benefited from this potential and have been trapped in low-income or middle-income status since WWII.

It has been argued that efficient institutions are the key to growth, and that the development of efficient economic institution in Western Europe accounts for the rise of the West (i.e. North and Thomas 1976, North 1990, Acemoglu and Robinson 2012). It is also widely agreed that institutions are persistent and it is unlikely that bad institutions in a country will improve spontaneously (North 1990; Acemoglu et al 2001). 
Countries with better institutions, more secure property rights, and less distortionary policies will invest more in physical and human capital, and will use these factors more efficiently to achieve a greater level of income (Acemoglu et al 2001). However, for countries that happen to have bad institutions that hamper economic growth, is there a way they can improve their institutions and develop their economies other than going back in time to change history?

As Keynes (1935, p. 384) said, "It is ideas, not vested interests, which are dangerous for good or evil". In this paper we will argue that the poor development performances in most developing countries are the result of inappropriate ideas about development and the role of the state. This paper explores the ideas of development and the role of the state in economic development and institutional change from the New Structural Economics (Lin 2011; 2012) perspective.

We argue that the state facilitates economic development by overcoming the inherent market failures in technological change, industrial upgrading and improvements of hard and soft infrastructure. These failures arise from various externalities, associated with first movers, and coordination problems, arising from improvement of hard infrastructure and institutions, in the process of structural transformation.

In our view the dynamic growth of an economy requires an organic relationship between the market and the state as follows: the market is efficient only if the state plays a facilitating role to overcome the inherent market failures and the goal of the state's facilitation is to ensure that the market is efficient. We also argue that, if there are right ideas, the state, no matter whether it be strong or weak, in a developing country could adopt and implement policies pragmatically to jump start a dynamic growth even though the country is beset with poor infrastructure and institutions. We are not arguing for more government controls over the market or more interventions in the market. What we argue here is that a facilitating state is a necessary condition for development. With right ideas it is possible for a developing country to start and sustain dynamic economic growth.

This paper aims to develop a new theory of facilitating states in economic development. It first reviews the previous ideas of development economics, with a focus on their view of the role of the state. Then present the main ideas of New Structural Economics and discusses the role of the state from the perspective of New Structural Economics. 


\section{Previous Generations of Development Economics ${ }^{3}$}

\subsection{Development Economics 1.0: Structuralism}

The first generation of development economists was Structuralists. After WWII, many developing countries shared a common aspiration for their people to enjoy the same living standard as citizens in the developed world. To achieve that goal, it was necessary for a developing country to have the same income and labor productivity as the developed countries; which in turn required having the same advanced industries as the developed countries. Whereas the reality was the developing economies were dominated by traditional agriculture and natural resource exploitation.

The desire to develop advanced industries in developing countries was also influenced strongly by the deterioration in the terms of trade between primary commodities and industrial products in the 1930s and 1940s during the Great Depression. The political leaders and social elites in many Latin American countries believed that the decline in the terms of trade against the export of primary commodities was secular and led to the transfer of income from resource-abundant developing countries to capital-abundant developed countries. They argued that the way for a developing country to avoid being exploited by developed countries was to develop domestic manufacturing industries through a process known as import substitution. Moreover, the emergence of previous colonies or semi-colonies as newly independent states in Asia and the Middle East, and later in Africa, was accompanied by strong nationalist sentiments.

According to Structuralism, developing countries could not develop advanced industries because they were beset with structural rigidities, causing market failures and inhibiting them develop advanced modern industries spontaneously. Structuralism advocates a developmental state, advising the governments of developing countries to adopt the import-substitution strategy with various price distortions and direct government mobilization and allocation of resources to develop advanced modern industries. This approach was also supported by the prevailing interventionist Keynesian economics at that time.

3 This section draws on Lin (2011) and Lin and Rosenblatt (2012). 
With the import-substitution strategy, many developing countries enjoyed a period of investment-led growth, but subsequently encountered stagnation and frequent crises. The income gap between developed and developing countries widened.

\subsection{Development Economics 2.0: Neoliberalism}

As government-led economic development strategies based on structuralism failed in many countries, the free market doctrine appeared to triumph and influence development thinking. The prevailing Keynesian macroeconomics was also challenged by the stagflation in the 1970s, the Latin American debt crisis, and the collapse of the socialist planning system in the 1980s. The so-called "rational expectations revolution" emerged and refuted the structuralist theoretical foundation for the state's role in using fiscal and monetary policy for economic development.

Neoliberalism emerged subsequently in the 1980s. It viewed government interventions as the main reason for the failure of developing countries to catch up with developed countries and recommended a set of neoliberal policies, encapsulated in the Washington Consensus, to overcome government failures by eliminating the interventions (Williamson 1990).

Neoliberalism promotes economic liberalization, privatization, and advocates a minimal state, advising developing countries to institute well-functioning market institutions similar to those in developed countries and believing that dynamic growth and structural transformation will happen spontaneously once there is a well-functioning market.

Under the guidance of Washington Consensus, many developing countries adopted a "shock therapy" to implement structural adjustment programs in the 1980s and 1990s for removing government interventions and distortions with policy advice and funding supports from International development institutions, like the World Bank and International Monetary Fund. The intention of structural adjustments was good, and the economic analysis of those programs appeared solid and convincing. However, the result was disappointing. The growth rate in the 1980s and 1990s was lower than that in the 1960s and 1970s, and the frequency of crises was even higher. Many developing countries experienced lost decades, with the income gap between developed and developing countries widening further (Easterly 2001). 


\section{A New Generation of Development Economics}

\subsection{New Structural Economics}

According to the World Bank's 2008 the Growth Report (Commission on Growth and Development 2008), after WWII there were 13 economies that achieved an outstanding performance of growing on average at seven percent or more continuously for 25 or more years. These 13 economies had the following five characteristics: (1) They were open economies; (2) They maintained macroeconomic stability; (3) They had high savings and high investment rates; (4) They had a well-functioning market mechanism, or were moving towards a market economy; (5) They all had credible, committed, and pro-active governments.

Michael Spence, the chairman of the Commission on Growth and Development, stresses that those five characteristics are ingredients of success but not a recipe for success. We argue that what is needed is a new development economics that is able to provide a consistent logic that encompasses the five characteristics of successful developing economics. In addition, we need to provide practical guidelines that developing country governments could follow.

The third generation of development proposed by Lin (2011 and 2012) labelled the New Structural Economics is an application of the neoclassical approach to study the determinants of economic structure, structural change and their impact on the evolution of development. As Rodrik (2011) explains “...developing countries are qualitatively different from developed ones. They are not just radially shrunk versions of rich countries. In order to understand the challenges of under-development, you have to understand how the structure of employment and production - in particular the large gaps between the social marginal products of labor in traditional versus modern activities - is determined and how the obstacles that block structural transformation can be overcome."

The main argument of New Structural Economics is that economic structures, including the structure of technology and industry, which determines labor productivity, and hard and soft infrastructure, which determines transaction costs, are endogenous to the endowment structure, which is given at any specific time and changeable over time.

Endowments and the endowment structure determine the economy's total budgets and relative factor prices at any specific time. These in turn determine the economy's comparative advantage and optimal industrial structure. That is, when the industrial structure is consistent with comparative advantage, as determined by the endowment structure, such a structure will have the lowest 
factor costs of production in domestic and international markets. Therefore, as an economy's structure of factor endowments evolves from one level of development to another, the optimal industrial structure of the given economy will evolve accordingly.

Income growth depends on upgrading the industrial structure to increase labor productivity, which in turn depends on the upgrading of the endowment structure, moving from labor intensive to capital intensive industries. With the upgrading of industrial structure, improvements in "hard" and "soft" infrastructure are required to reduce transaction costs and risks.

Following comparative advantage (determined by the endowment structure) to develop industries is the best way to achieve dynamic growth and convergence. The economy with such industries and appropriate hard and soft infrastructure will be most competitive, produce the largest surplus, have the highest possible returns to capital and thus savings, ensure the fastest upgrading of the endowment structure, and achieve the most rapid industrial upgrading and income growth ( $\mathrm{Ju}$, Lin and Wang 2015). In this process, a developing country can have latecomer advantages and thus have a faster technological innovation and industrial upgrading than high-income countries, which leads to faster growth and convergence with high-income countries.

For the entrepreneurs, what they care about is profitability. How to translate the concept of following a country's comparative advantages to influence the spontaneous choice of entrepreneurs? This requires a well-functioning market so that the relative factor prices reflect the relative supply of factors in the endowments. With such relative factor prices, entrepreneurs for their own profitability and competitiveness in the market will enter industries and adopt technologies which are consistent with the comparative advantage determined by factor endowments.

But economic development is a dynamic process. It's a process of continuous technological innovation and industrial upgrading. Such upgrading and improvements require first movers. Two market failure issues arise during that process. One is the externality, i.e. the government needs to provide incentives for the first mover. And the second is coordination for improving institutions and infrastructure, which affect transaction costs and the first movers' probability of success. Thus, in addition to an effective market mechanism, the government should play an active role in facilitating structural change.

Those two conditions of efficient markets and facilitating state are precisely the stylized facts 4 and 5 of the Growth Report. If a country follows its comparative advantage in their development, it will open its economy to the world market (fact 1) and achieve macroeconomic stability due to its 
competitiveness (fact 2). Following comparative advantages will generate the largest surplus and highest incentives for savings and investments (fact 3). So following comparative advantage is a prescription for development success (Lin 2012, chapter 2).

From the perspective of New Structural Economics, Structuralism failed because it ignored the endogeneity of economic structure of a country and recommended promotion of certain industries that were too advanced for the country's level of development and defied the comparative advantages of that country. The firms were non-viable in open competitive markets and required government subsidies and protection for their initial investment and continuous operations. This led to a misallocation of resources, rent-seeking, corruption, and political capture. The successful East Asian economies instead adopted an export-oriented development strategy to develop labor-intensive manufacturing, exploiting the comparative advantages determined by their abundant labor supplies in the 1950s and 1960s. This later strategy was not one that was recommended by Structuralists.

The Washington Consensus, based on Neoliberalism, failed because it ignored the fact that the distortions in developing countries were designed to protect nonviable firms in the priority sectors (due to the previous comparative advantage-defying strategy) and advised governments to eliminate all distortions immediately, causing the collapse of old priority sectors and deindustrialization. The Washington Consensus also opposed the government adopting a sectortargeted policy to provide externality compensation incentives and overcome coordination failures by improving necessary hard and soft infrastructure to facilitate a firm's entry into sectors consistent with the country's comparative advantage.

For transition economies, which achieved stability and dynamic growth during their transition processes, such as China, Vietnam and Cambodia in the 1980s and Mauritius in the 1970s, their governments adopted a pragmatic dualtrack approach: on the one hand, providing continuously transitional support to nonviable firms in the old priority sectors and removing distortions only when firms in those sectors became viable or the sectors become very small, and on the other hand, their governments facilitated private firms' entry into sectors that were consistent with the country's comparative advantage, which was previously repressed before the transition. The latter can be achieved by setting up special economic zones/industrial parks to overcome infrastructure constraints; ${ }^{4}$ providing one-stop service to improve the business environment;

4 Most special economic zones in many countries fail because of failures in infrastructure and/ or lack of effective regulations and regulation implementation, or because the zones had 
and engaging in active investment promotion to attract foreign firms' investment in these countries as part of their global value chains. They would thus gain access to the global market (Lin 2013).

Such a strategy contributed to stability and dynamic growth and is favorable to domestic capital mobilization and FDI. Ironically, the dual track approach was viewed as the worst transition approach from the Neoliberal point of view (Murphy, Shleifer and Vishny 1992).

\subsection{Barriers to Development and Industrial Policies}

New Structural Economics argues that the state has an essential role in facilitating rapid technological innovation, industrial upgrading and diversification because of the need to address externalities and solve coordination problems in the improvement of infrastructure and institutions. Industrial policy is a useful instrument for a state to facilitate structural transformation. This is because the required coordination for improvements in infrastructure and institutions may differ among industries and locations, and the government's resources and capacity are limited so the government needs to use them strategically. ${ }^{5}$

However, for an industrial policy to be successful, it should target sectors that conform to the economy's latent comparative advantage. The latent comparative advantage refers to an industry that has competitive, low factor costs of production internationally, i.e., consistent with the country's comparative advantage determined by its factor endowments, but the transaction costs are too high, due to inadequate hard and soft infrastructure, to be competitive in domestic and international markets.

Firms in an industry with latent comparative advantages will be viable and the sectors can be competitive once the government helps the firms overcome coordination and externality issues in the improvement of hard and soft infrastructure to reduce transaction costs and risks. But how can the government pick the sectors that are in line with the economy's latent comparative advantages? Depending on a targeted industry's distance to the global technology frontier, New Structural Economics classify industries in a developing country, especially a high-middle income country like China, into five categories and recommends government's facilitation according to their respective needs for growth (Lin 2017):

been located in the wrong place due perhaps to political motivation, or because the zones target industries were not ones in which the country had a comparative advantage.

5 See Aghion and Rouglet (2014) and Aghion et al (2015) for more discussion on the role of the state and industrial policy. 
(1) For industries that a country still has a distance to the global technology frontier, the government should find out the binding constraints in infrastructure, financing, human capital, etc., for their catching up and help to remove them.

(2) For industries that a country is already on the global frontier, the government should support firms to do R\&Ds to maintain the industry's technological leadership globally.

(3) For industries that have already lost their comparative advantage, such as labor-intensive industries in China, the government should help firms either to shift to branding, product designs and marketing management, of which the returns are high, or relocate to countries with low wages.

(4) For short innovation-cycle industries, which rely more on human capital than physical capital, countries with abundant human capital, and especially like China also with its own large domestic market, the government can set up incubation parks, encourage venture capitals and protect intellectual property to facilitate innovations.

(5) For industries that are strategically important for national defense but the country does not have comparative advantage, the government should subsidize them directly with fiscal expenditure instead of price distortions and other market interventions.

\section{The Facilitating State, Political Leaders and Ideas}

\subsection{Road to Development}

A developing country is likely to be beset with not only low productivity industries and poor infrastructure but also backward, grabbing or distorted institutions. Institutions shape the incentives of a society. New Institutional Economics believe that a country will have dynamic growth and become rich if it has good institutions to provide incentives for work, accumulate human and physical capital, acquire better technology and improve resource allocation (North and Thomas 1973; North 1981, 1990). If a country has poor institutions-which deprive people of the incentives to do the right thing for economic growth-it will be poor and will stagnate. For example, Acemoglu et al (2001) and Acemoglu and Robinson (2012) argue that United Kingdom and the United States are rich because they have inclusive institutions that limited the power of the elites and created a society in which political rights are 
widely distributed. Latin America and Africa are poor because of the extractive institutions.

In addition to arguing that institutions matter, New Institutional Economics also claims that institutions are endogenous, and are determined by other social, economic and political factors in the economy (North 1981; North and Thomas1973). Moreover, institutions that existed hundreds of years ago still have an important impact on the current institutions and level of economic development, because institutions are determined also by culture and history, and thus institutional change is path dependent (Acemoglu et al 2001, North 1981).

Following the above logic, the backwardness of institutions explains why poor countries are poor and why they have failed to develop. As such, the state and people are powerless because institutions cannot be exogenously changed. If the line of reasoning by the New Institutional Economics is accepted, the study of development would be a very dismal subject, as it cannot put forward any solution to the development problem.

A quick observation of the economies in the East Asian Miracle (World Bank 1993) and the 13 successful economies in the report of Commission of Growth and Development (2008) show the following common features: in spite of being trapped in poverty and beset with bad institutions previously, they all had committed, credible and capable government and the state adopted the rule of law and other regulations that are consistent with modern economic growth and policies to pursue an export-oriented strategy exploiting the comparative advantages based on their development stages. ${ }^{6}$ Therefore, it is possible to break the grip of bad institutions if the state plays an appropriate function.

However, looking back at the economic growth of the world, it is not difficult to see that the majority of the poor countries did not governments that had the right idea of how to develop and provide a sufficiently productive business environment and efficient public services (Besley and Persson 2009, Bardhan 2016).

In any development stage, the state has to play a proactive, facilitating role. The constraints on economic development that the state needs to remove will be different for different countries and for a country in a different development stage. In the early stage of development in a country, the constraints are likely

6 It should be noted that many other countries also introduced the rule of law and other regulations but failed to achieve modern economic growth. The key here is not whether the rule of law is introduced but that it is accompanied with a development strategy to promote industrial development in line with a country's comparative advantage. This will be discussed later. 
to be poor infrastructure, low skills, bad business environment, and backward institutions, and additionally various distortions and interventions if the country is on a transition process from a structuralist development strategy to marketoriented economy. For a developed country, the constraints are most likely to be the breakthrough in basic science required for the development of new technology/products or laborers' skill for working in new industries. If an efficient institution and a productive business environment cannot evolve spontaneously and infrastructure cannot be provided by the private sector, the state is needed to induce and develop them to facilitate the growth of the economy.

\subsection{The Role of Political Leaders}

Political leaders operate the government. If we want to analyze the quality of a government's policies and regulations, we need to understand what motivates the political leaders to determine government policies (Lin, 1989). In any system, a political leader's personal interest is to 1) stay in power and 2) to leave a legacy and have a good name in history if staying in power is not under challenge (Lin 2009). The best way to stay in power and to have a good legacy in history is to bring prosperity to the nation. In this way, the political leader will be supported by the people and have a good name in history. However, when the ideas the political leader follows and the policies do not bring prosperity to the nation, the political leader may lose the support of the people and his leadership may be challenged. For the purpose of staying in power, the political leader may create supporting vested-interest groups by patronage to consolidate his/her control at further costs of prosperity in the nation. There will be a vicious cycle. Therefore, an expropriating state and grabbing elites are the likely consequences of the political leader's inability to bring prosperity to a nation.

Although a political leader has to follow certain conventions and are also constrained by either the elites or the people who put him/her in power, a political leader can use his/her discretionary power to make many things happen. The key for success in a developing country with poor infrastructure and institutions is for the leader of the country to use his/her discretionary power to generate quick wins to jumpstart modern economic growth by creating enclaves such as special economic zone, which have good infrastructure and business environment, to turn industries of the country's latent comparative advantages into competitive advantages. Such quick wins will generate a virtuous cycle by generating more resources for expanding infrastructure and business environment improvements to other parts of the nation. The quick 
wins will also enhance the political leader's authority for making more desirable institutional changes. With dynamic growth, a new entrepreneurial class will arise and the power of old vested-interests elite will decline. Therefore, this pragmatic approach can be used to break the institutional deadlock in a country beset with grabbing-hand vested interests politics, bad institutions or excessive distortions and interventions inherited from the past (Lin and Monga 2017).

Park Chung-hee in South Korea, Chiang Kai-shek in Taiwan, China, Lee Kuan Yew in Singapore in the 1960s and Deng Xiaoping in mainland China since 1979 played an instrumental role in jump-starting the development process that transformed their economies even though their economies like those in other developing countries were trapped in poverty and beset with poor infrastructure and bad or distorted institutions before starting the dynamic transformation. There has been some empirical literature showing that changes in the national leader can matter significantly for economic growth. Jones and Olken (2005) find that leadership transitions are associated with shifts in country growth rates.

Even for a political leader who inherits an expropriating state and grabbing elites, if there is a theory for bringing inclusive and dynamic growth quickly, they will have the incentive to use their discretionary power to follow it, probably in a pragmatic process, in which the vested interests are protected to maintain political/social stability and a new niche of growth is ignited such as in the dualtrack transition in Mauritius in the 1970s and China and Vietnam in the 1980s, to generate a virtuous cycle of growth. ${ }^{7}$

\subsection{Right Ideas and Appropriate Development Strategies}

In pursuing modernisation, political leaders in developing countries adopted certain strategies - which consisted of a set of policies, including various interventions and regulations - as a vehicle to achieve their goals. The set of policies shaped the development and quality of institutions in their countries, which in turn affected their economic performance (Lin 2009). Due to the complex nature of modernization in a developing country and the political leaders' bounded rationality in understanding the subject, it was practical for political leaders to follow the dominant social thought in the pursuit of national development. It was the dominant social thought that shaped the institutional order of developing countries.

7 See Chapter 2 of Lin (2009) and Lin and Monga (2017) for more detailed discussion. 
Unfortunately, the dominant social thought about achieving modernisation was based on incorrect perceptions of the root causes for and constraints on a developing country's modernisation. Many of the strategies were under the influence of the previous generations of the development economics which has misled many of the leaders and economic policies of these countries. They not only failed to deliver the promise of making their countries as successful as developed countries, but also caused stagnations, frequent crises and even disastrous consequences in their economies (Lin 2009). Only few economies escaped the influences of the dominant social thought at that time, such as the East Asian tigers in the 1960s and China in the 1980s. The leaders of these governments were not influenced by the dominant social thought at that time but adopted a pragmatic approach during the transformation process. ${ }^{8}$

Frictionless transactions, complete information and clearly defined property rights are desirable but do not normally exist in real world, especially developing economies. The government of a developing country may try to impose developed country's style of institutions with an attempt to improve the factor market and the product market efficiency, enhance the transparency of the information, reduce the friction in transactions and so on, but such institutional changes are difficult to achieve as institutions tend to be persistent and path-dependent. Without an endogenous force for change, the imposed institutions may not function as intended (Lin 1989). Thus it is necessary to understand and solve the development problem from the endowment structure of the economy, including its institution, rather than starting from the efficient market assumptions of the neo-classical economics.

Low-income countries are often beset with backward or distorted institutions. The issue is not whether they have an effective or strong state to overcome the institutional barriers but how the political leader uses their discretionary power to jump-start development. The difference between New Structural Economics and other development thinking is as follows: The New Structural Economics advocates a developing country should look at what it can do well based on what it has now and create conditions to scale up what it can do well, instead of looking at what it does not have or cannot do well based on what the highincome countries have and can do well and try to have or do as the high-income countries do.

The key point here is that the state has to follow a right strategy in a pragmatic way, to best utilize the resources in the economy and to create incentives for individual and private firms to pursue economic activities that

8 See Buera and Shin (2010) for a discussion of how social thought has significant impact on the economic growth of a country. 
will increase the income level of the country. A right approach guided by a right idea is more important than a strong state recommended by some economists. If the development strategy is wrong, a strong state may cause more harm to its people and country than a weak state. Therefore, a strong state is a two-edge sword, as argued by North (1981, p. 20).

In other words, in order to jump start the development process and sustain it, there must be a facilitating state that is able to provide basic public infrastructure and to help the latent comparative advantage industries become competitive by improving infrastructure and institutions. Even in a state with limited capacity and resources, an inheritance of poor institutions, and beset with vested-interested group politics, it is still possible for the political leader, if he/she has the right ideas, to use his/her discretionary power and resources to create enclaves, such as special economic zones and industrial parks, with good infrastructure and one-stop service, to jump-start a dynamic growth in a Pareto improving manner.

The dynamic growth, even starting in small enclaves, will give the hope to the people, enhance the political strength of the leader, and generate more resources for further changes in the economy. It is just like the best performing African country Mauritius' transition in the 1970s. It inherited a Western multiple-party democracy, a monoculture in sugar, distorted institutions due to the structuralist import-substitution strategy and did not have a strong state, but it has achieved significant growth in both living standard and the state capacity by starting its transition from an textile and garments export processing zone in the 1970 (Subramanian and Roy 2003). Its per capita GDP reached USD 9,628 in 2016. This is also how China, Vietnam and a few other East Asian countries are able to grow dynamically, even though their institutions were very poor and are still poor measured by many macroeconomic indicators including Doing Business Indicators and Corruption Perception Index.

On the contrary, if the idea for development is wrong, for example the structuralism for development and neoliberalism for transition, even a country with a strong state capacity, such as Soviet Union, bountiful resources, such as Argentina and many other Latin America countries, or with a good institution at the beginning such as the Philippines, India and other post-colonial developing countries, the development performance will be poor. Therefore, the fundamental determinant for development success or failure in any country under any preconditions is ideas. ${ }^{9}$

$9 \quad$ See Lin (2009) and Lin and Monga (2017), for some detailed arguments along these lines 


\section{Conclusions}

The mainstream in economics has been dominated by the Neoclassic Economics since the Second World War, but the role of the state is missing in it. Many other forms of development economics have government playing various roles but they have proven unsatisfactory.

Structuralism advocates a developmental state and is usually pursuing ambitious industrialization against comparative advantages. The goal was to build up advanced modern industries and use the government's protection and subsidies as policy instruments. Neoliberalism advocates a minimal state and opposes the use of industrial policy. Its goal is to build up a well-functioning market institutions, and it believes structural change will happen spontaneously in a well-functioning market.

Neoclassical economics address the problem of efficient markets; New Institutional Economics provides a theory of the role of the institutions and illustrates the importance of the institution. The New Structural Economics argues that the state matters and the right idea matters. It explains and shows how to achieve the optimal development results with a given endowment structure, with the government's proactive policy. New Structural Economics puts the state and strategy of development and transition right in the center of the new generation of developmental economics.

This paper focuses at the role of the state from the new structural economics point view. New Structural Economics advocates a facilitating state. Its role is to facilitate structural change by using industrial policy to overcome market failures in order to help industries with latent comparative advantages to become competitive advantages in the market and a pragmatic, gradual, dual-track approach for transition to achieve stability and dynamic growth.

This paper provides guidance as to how governments should direct the economy and emphasizes that government should promote the economy in a way that is consistent with its comparative advantage. This paper also develops a theory of facilitating states and argues that the conventional literature missed an important role of the state: inducing institutional change and facilitating economic development.

A less developed country is associated with low physical capital accumulation, low human capital level, poor infrastructure and backward or distorted institutions, which are the barriers to development. We argue that political leaders can play crucial roles in shaping the growth of nations. However, this is not about strong or weak state. Political leadership and pragmatism are essential for jump-starting development in developing countries. 
If the idea is right, even if the state in weak at the beginning it is still possible for the state to create enclaves, such as special economic zones, to help industries of the country's latent comparative advantage to quickly become the country's actual competitive advantage, and start a virtuous cycle of development. If the idea is wrong, for example China's heavy industry oriented development strategy before the transition in 1979 and the shock therapy in Russia's transition in the 1990s. Those ideas resulted in slow income growth and low levels of economic development.

This paper argues for a proactive role of the state. We recognize that the government failure prevail in history and many parts of the world today. Lewis (1955, p. 376) observes: "No country has made economic progress without positive stimulus from intelligent governments. ... On the other hand, there are so many examples of the mischiefs done to economic life by governments." However, Stiglitz (2011) is right to argue that interventions will never be perfect, the choice is between imperfect governments and imperfect markets, each of which has to serve as a check on the other; they need to be seen as complementary, and we need to seek a balance between the two - a balance which is not just a matter of assigning certain tasks to one, and others to the other, but rather designing systems where they interact effectively.

To reduce the chance of inappropriate interventions and increase the probability of success, the New Structural Economics advocate an organic relation between the market and the state in which "the market is efficient only if the state plays a facilitating role to overcome the inherent market failures and the end of the state's facilitation is to ensure the market to be efficient". The New Structural Economics also advocate that the state should pragmatically prioritize the use of its limited resources and implementation capability to overcome constraints for scaling up industries in which the country has a latent comparative advantage (what they can do well), based on the country's existing endowments (what they have now). If the political leader in a developing country can follow such advice, any developing country can jump start a dynamic growth path for inclusive and sustainable development even though the country may be trapped in poverty for centuries and be beset with poor infrastructure, bad institutions and vested-interest politics.

\section{References}

Acemoglu, D., Johnson, S. and Robinson, S. (2001). The Colonial Origins of Comparative Development: an Empirical Investigation. American Economic Review, 91(5), 1369-1401. 
Acemoglu, D. and Robinson, J.A. (2012). Why Nations Fail: The Origins of Power, Prosperity, and Poverty. New York: Random House, Crown Business.

Agenor, P.R., Canuto, O. and Jelenic, M. (2012). Avoiding Middle-income Growth Traps. Economic Premise, 98. World Bank.

Aghion, P., Cai, J., Dewatripont, M., Du, L., Harrison A. and Legros, P. (2015). Industrial Policy and Competition. American Economic Journal: Macroeconomics, 7(4), 1-32.

Aghion, P. and Roulet, A. (2014). Growth and the Smart State. Annual Review of Economics, 6(1), 913-926.

Bardhan, P. (2016). State and Development: The Need for a Reappraisal of the Current Literature. Journal of Economic Literature, 54(3), 862-892.

Buera, F.J. and Shin, Y. (2010). Financial Frictions and the Persistence of History: A Quantitative Exploration. Journal of Political Economy, 121(2), 221-272.

Commission on Growth Development. (2008). The Growth Report: Strategies for Sustained Growth and Inclusive Development. Commission on Growth and Development Final Report. Washington, DC: World Bank.

Easterly, W. (2001). The Lost Decades: Explaining Developing Countries' Stagnation in Spite of Policy Reform 1980-1998. Journal of Economic Growth, 6(2), 135-157.

Jones, B. and Olken, B. (2005). Do Leaders Matter? National Leadership and Growth Since World War II. Quarterly Journal of Economics, 120(3), 835-864.

Ju, J., Lin, J.Y. and Wang, Y. (2015). Endowment Structures, Industrial Dynamics, and Economic Growth. Journal of Monetary Economics, 76, 244-263.

Keynes, J.M. (1935) [1964]. The General Theory of Employment, Interest, and Money (first Harbinger edition). New York, Chicago, Burlingame: Harcourt, Brace and World.

Kuznets, S. (1966). Modern Economic Growth: Rate, Structure, and Spread. New Haven, CT: Yale University Press.

Lewis, A. (1966). Theory of Economic Growth. London: Allen and Unwin.

Lin, J.Y. (1989). An Economic Theory of Institution Change: Induced and Imposed Change. Cato Journal, 9(1), 1-33.

Lin, J.Y. (2009). Economic Development and Transition: Thought, Strategy and Viability. Cambridge, UK: Cambridge University Press.

Lin, J.Y. (2012). New Structural Economics: A Framework for Rethinking Development and Policy. Washington DC: the World Bank.

Lin, J.Y. (2013). Demystifying the Chinese Economy. The Australian Economic Review, 46(30), 259-268.

Lin, J.Y. (2017). Industrial Policies for Avoiding the Middle-income Trap: a New Structural Economics Perspective. Journal of Chinese Economic and Business Studies, 15(1), 5-18.

Lin, J.Y. and Monga, C. (2017). Beating the Odds: Jump-starting Developing Countries. Princeton, NJ: Princeton University Press.

Lin, J.Y. and Rosenblatt, D. (2012). Shifting Pattern of Economic Growth and Rethinking Development. Journal of Economic Policy Reform, 15(3), 171-194.

Lucas, R.E., Jr. (1990). Why Doesn't Capital Flow from Rich to Poor Countries? American Economic Review, 80(2), 92-96.

Mankiw, G., Romer, D. and Weil, D.N. (1992). A Contribution to the Empirics of Economic Growth. The Quarterly Journal of Economics, 107(2), 407-437.

Murphy, K.M., Shleifer, A. and Vishney, R.W. (1992). The Transition to a Market Economy: Pitfalls of Partial Reform. Quarterly Journal of Economics, 107(3), 889-906.

North, D.C. (1981). Structure and Change in Economic History. New York: W.W. Norton \& Co. 
North, D.C. and Thomas, R.P. (1976). The Rise of the Western World: A New Economic History. Cambridge: Cambridge University Press.

North, D.C., Wallis, J.J. and Weingast, B.R. (2009). Violence and Social Orders: a Conceptual Framework for Interpreting Recorded Human History. Cambridge University Press.

North, D.C. and Weingast, B.R. (2000). Introduction: Institutional analysis and economic history. The Journal of Economic History, 60(02), 414-417.

Rodrik, D. (2006). Goodbye Washington Consensus, hello Washington Confusion? A Review of the World Bank's Economic Growth in the 1990s: Learning from a Decade of Reform. Journal of Economic Literature, 44(4), 973-987.

Solow, R. (1956). A Contribution to the Theory of Economic Growth. Quarterly Journal of Economics, LXX, 65-94.

Williamson, J. (1990). What Washington Means by Policy Reform. In: J. Williamson (ed.), Latin American Adjustment: How Much Has Happened? Washington: Institute for International Economics.

World Bank. (1993). The East Asian Miracle: Economic Growth and Public Policy. Oxford, UK: Oxford University Press. 